Rev. Int. Contam. Ambie. 35 (Environmental Engineering of Sustainable Landscapes) 53-63, 2019

DOI: 10.20937/RICA.2019.35.esp01.06

\title{
PARTICLE IMAGE VELOCIMETRY AND NUMERICAL STUDIES OF ARTIFICIAL UPWELLING VIA DIFFERENTIAL HEATING IN OPEN SURROUNDINGS
}

\author{
Ming LV, Yuanzhe MAO, Mengqin XIA, Haiqiang LIU*, Xin NIE, Xiaoqin TIAN, \\ Huachen PAN and Zefei ZHU
}

School of Mechanical Engineering, Hangzhou Dianzi University, Hangzhou Zhejiang 310018, China

*Corresponding author: jxliuhaiqiang@hdu.edu.cn.

(Received May 2018; accepted July 2018)

Key words: artificial upwelling, differential heating, numerical simulation, PIV

\begin{abstract}
Artificial upwelling is considered as a promising technology to recover the marine environment, especially for fishery environment recovery. This paper studied basic characteristics of "differential-heating- liquid- upwelling" (DHLU) in open surroundings with PIV and numerical analysis. Flow field of upwelling under typical condition was measured with particle image velocimetry (PIV), and a reasonable numerical model was built on the base of experimental data to study the key characteristics of DHLU system by numerical simulations. Results show that the upwelling in DHLU is mainly driven by the masses with high ascending speed. It is reasonable to choose k- $\varepsilon$ turbulence model to study the flow field of DHLU in simulation. All of the three important parameters such as characteristic ascending speed, the cross-sectional area of upwelling stream and the upwelling's flow rate are all increase firstly and then decreases while the height from the heating source increases. But the position of maximum value for characteristic ascending speed is much lower than the other two parameters. The drop of ambient temperature is not favorable for the production of upwelling. A flow rate as high as $95.9 \mathrm{~cm}^{3} / \mathrm{s}$ was reached in studied cases in this paper.
\end{abstract}

Palabras clave: surgencia artificial, calentamiento diferencial, simulación numérica, PIV

\section{RESUMEN}

La surgencia artificial se considera como una técnica prometedora para la recuperación de ambientes marinos, especialmente para pesquerías. Este trabajo estudia las características básicas del calentamiento líquido diferencial de surgencias (DHLU, por sus siglas en inglés) en ambientes abiertos con velocimetría de imágenes de partículas y análisis numérico. El campo de flujo de la surgencia en condiciones típicas se midió con PIV y se construyó un modelo numérico razonable con base en datos experimentales para estudiar las características clave del DHLU con simulaciones numéricas. Los resultados muestran que la surgencia en un sistema DHLU producida principalmente por las masas con velocidad ascendente. Es razonable escoger el modelo de turbulencia k-e para estudiar el campo de flujo DHLU en la simulación. Los tres parámetros importantes como la velocidad característica de ascenso, el área de sección de la corriente de la surgencia y la tasa de flujo de la surgencia, se incrmentan primero y luego disminuyen mientras la altura desde la fuente de calor aumenta. Pero la posición del valor máximo para la velocidad 
característica ascendente es mucho menor que los otros dos parámetros. La caída de la temperatura del ambiente no es favorable para producción de la surgencia. En los estudios de caso reportados en este trabajo se alcanzó una tasa de flujo tan alta como $95.9 \mathrm{~cm}^{3} / \mathrm{s}$.

\section{INTRODUCTION}

Upwelling can bring the nutrients which are rich in deep seas to the surface of ocean, and then the phytoplanktons which is at the bottom of most marine food chains can be fed. That can bring suitable living environment for fish and other marine organisms (Williamson 2009, Li et al. 2018). So, the areas with natural upwelling are the most productive ocean fishing grounds in the world (Ryther 1969, Teng and Zhou 2017).

In recent years, the global offshore ecological environment has been worth. And the fishery resources declined (Brian 2003, Usman et al. 2017). Natural ocean upwelling has disadvantages because of its seasonal and spatial limitations (Jeffrey 2001, Mi et al. 2016, Yu 2001). Artificial upwelling can make up for those limitations and play an important role in the marine environment recovery and the fishery resources development (Fu and Liu 2017, Yang et al. 2017, Dzida and Girtler 2016). In addition, upwelling has been found as a promising way to reduce the accumulation of anthropogenic carbon dioxide in the atmosphere (Pan et al. 2015, Fu and Liu 2017, Anees et al. 2017).

In the past few decades, artificial upwelling technologies have been studied, and many research achievements have been gained. A group researcher developed an artificial upwelling device called "Takumi" (Kazuyuki and Alan 2003, Kazuyuki and Hiroyuki 1999, Franco et al. 2017). The device had a large floating offshore platform. And it used pump to lifting nutrients from deep sea. The prototype of the machine was manufactured and set-up at the center of Sagami Bay in Japan. However, the upwelling flow rate is only about $1.2 \mathrm{~m}^{3} / \mathrm{s}$.

Another group of researchers proposed to make artificial upwelling by using wave pump which was combined with check valve (Isaacs et al. 1976, Liu 1999, Liu and Jin 1995, Cheung et al. 2017). The main principle of the wave driving device is that the valve is only open on the down slope of a wave and close on the up slope. An estimated flow rate is about 0.45 to $0.95 \mathrm{~m}^{3} / \mathrm{s}$ for a wave height of $1.90 \mathrm{~m}$ and a wave period of $12 \mathrm{~s}$ (Angelicque 2010, Tan et al. 2017).

A group researcher proposed an artificial upwelling system based on the concept "perpetual salt fountain". In many areas of the tropical and subtropical ocean, warm salty water overlies colder fresher water (Tsubaki et al. 2007, Singh et al. 2018, Rogers et al. 2016, Khan et al. 2017). And that causes a famous vertical convective motion calling "salt finger". The salt fingers occur because of the difference in the diffusivities of heat and salt. When a pipe is inserted to connect deep sea and the surface, and the pipe is filled with the low salinity deep sea water, the salinity of the water inside the pipe is lower than that outside (Kori et al. 2018). The upwelled deepsea water becomes almost the same temperature as the surrounding water. Hence buoyancy occurs in the pipe. The upwelling flow can be continuing as long as the differences of the temperature and salinity exist. The flow rate with a single pipe was estimated at approximately $45 \mathrm{~m}^{3} /$ day.

Some researchers proposed an air-lift pump for upwelling deep ocean water (Liang et al. 2005). For the air-lift pump the air is compressed into a vertical pipe, dipped in water. Bubbles ascend and the water level in the pipe rises due to the density decrease in the air-water mixture (Halin et al. 2017). Once the water level reaches the top of the pipe and the water flows out, the water flows continuously from the lower end. For the air-lift pump the seawater flow rate ratio could be hundred times higher when compared to the air flow rate. A studied the air-lift pump experimentally and the effect of the air-lift upwelling method was confirmed (McClimans et al. 2010, Fan et al. 2013). Some researcher tried to apply the air bubbler technology in ice control of harbours (Pan and Eranti 2007, Pan and Eranti 2009). A studied the influence of the bubble parameters on the upwelling flow rate (Tian et al. 2014). Other studied on the influence of air-lift artificial upwelling on water temperature (Leng et al. 2014, Zaidi et al. 2017).

A group researcher proposed an artificial upwelling technology via differential heating method, which was named "Differential-Heating-Liquid-Upwelling" (DHLU) (Lv et al. 2014). This renovation technology is bases on the phenomena that the vertical temperature gradient of fluid, which is hot at bottom and cold at top, can cause the vertical density gradient inside the fluid, which will cause the inner vertical convection of the fluid for the reason of buoyancy. This technology tries to transfer the solar heat into deep 
seawater and heats the deep seawater to make a local warm zone. It is proved that the warm zone located in deep water can produce effective upwelling in water.

In this paper, we studied the flow field characteristics of DHLU system with PIV experiments and CFD numerical simulations. First, we measured and analyzed the flow field characteristics of DHLU in typical cases by PIV experiments. And then, the CFD numerical model was built according to the experimental results. Next, several numerical simulation studies were carried out to explore the influences of some important factors on the flow field characteristics. Finally, some conclusions are summarized.

\section{EXPERIMENTS}

\section{Experimental setup}

Our laboratory has established the experimental system of DHLU. The schematic view of the system is shown in Fig.1. The system consists of five parts, including a glass tank, a heating system, a cooling system, a temperature measure system, and a PIV system. The experimental system can simulate the marine environment, and make temperature differences artificially to create upwelling, and measure the velocity field of upwelling.
The glass tank was used to modelling the environment of the upwelling. Its size was $700 \times 400 \times 550$ $\mathrm{mm}$. The tank was filled with water. The depth of water was kept at $500 \mathrm{~mm}$. At the top of the tank there was a water cooler. The water cooler was immerged into water and it was made by a continuously curved copper tube, which was connected with a cryostat circulator. The water cooler and the cryostat circulator composed the cooling system, which temperature could be set to a fixed value with a precision of \pm $0.05^{\circ} \mathrm{C}$. The cooling system was used to keep the temperature of the top water layer at a constant lever.

The heating system consisted of a heating stick and a temperature \& power controller. The heating stick was fixed vertically at the bottom center of the glass tank, as Fig. 1 shows. The height of the heating stick's head from the bottom of tank was fixed at $75 \mathrm{~mm}$. Rubber seals were used to seal the heating system. The temperature \& power controller could control the heating temperature or the heating power of the heating stick. In our experiment, we chose to control the heating power.

The temperature measure system consisted of a data logger (model HP34970A, Agilent Technologies, Inc.) and a group of eight K-type thermocouples. Those thermocouples distributed along a thin straight metal rod for every 50mm, as shown in Fig. 1. The

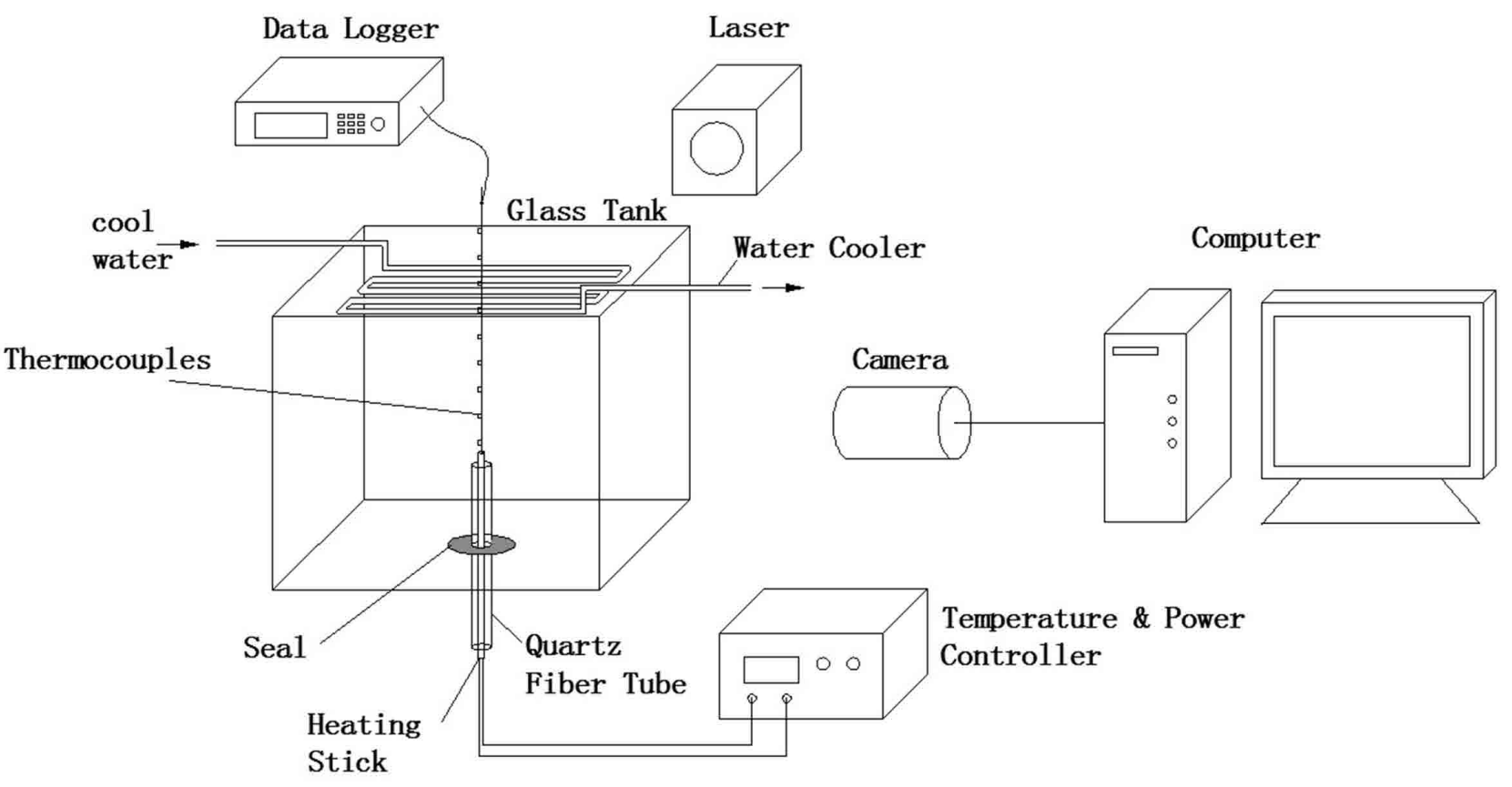

Fig. 1. The schematic view of the system 
bottom thermocouple is $10 \mathrm{~mm}$ away from the top of the heating stick. The temperature measure system is used to measure the vertical temperature distribution of upwelling centre.

The PIV system (model V3V-2D PIV, TSI Co.ltd, USA) was used to measure the velocity field of the upwelling. The PIV system includes a laser (Nd:YAG laser, $350 \mathrm{~mJ}, 15 \mathrm{~Hz}$ ), three cameras (PowerView Plus $4 \mathrm{MP}, 2 \mathrm{~K} \times 2 \mathrm{~K}$ pixels ), and a synchronizer. In this paper, 2D PIV experiments were carried out to study the flow field characteristics of DHLU system.

In the typical experimental case, the power of heating stick was set at $100 \mathrm{~W}$. And the initial water temperature was set at $15^{\circ} \mathrm{C}$. In each case, the temperature of water in the glass tank and the cooling system were all set at $15{ }^{\circ} \mathrm{C}$ firstly. And then the heating stick heated at a constant power of $100 \mathrm{~W}$. After about $10 \mathrm{~min}$, when there was steady upwelling that could be observed in tank, PIV system started to measure the flow field.

\section{Experimental results and discussion}

When the initial water temperature was $15^{\circ} \mathrm{C}$ and the heating power was $100 \mathrm{~W}$, the instantaneous vertical velocity field and vorticity field of upwelling which was measured by 2D-PIV in a certain state are show in Fig. 2 and Fig.3. Here we are primarily concerned with the ascending velocity of upwelling. So, we discussed mainly about the Y-direction velocity component of velocity field, which positive direction means ascending direction. Results show that there

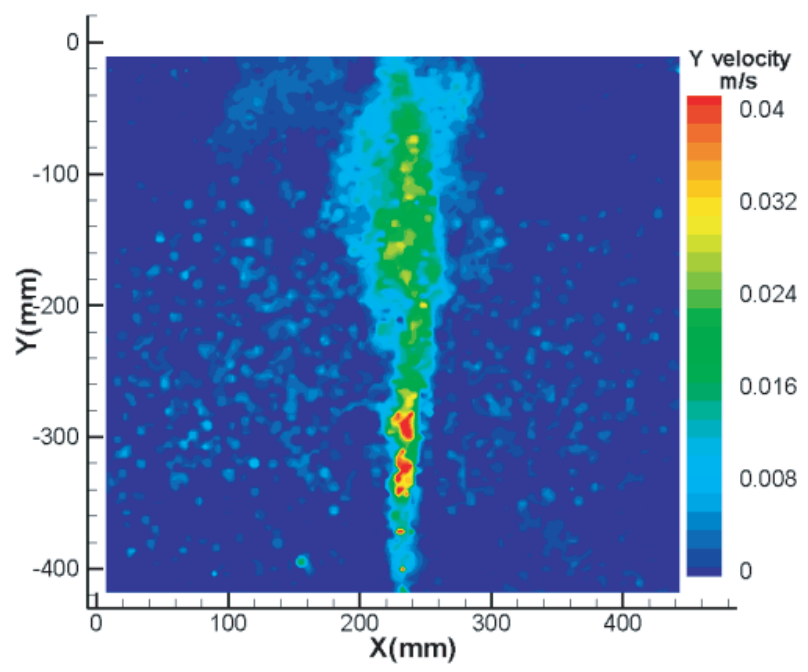

Fig. 2. The instantaneous vertical velocity field of upwelling (The initial water temperature was $15^{\circ} \mathrm{C}$ and the heating power was $100 \mathrm{~W}$ )

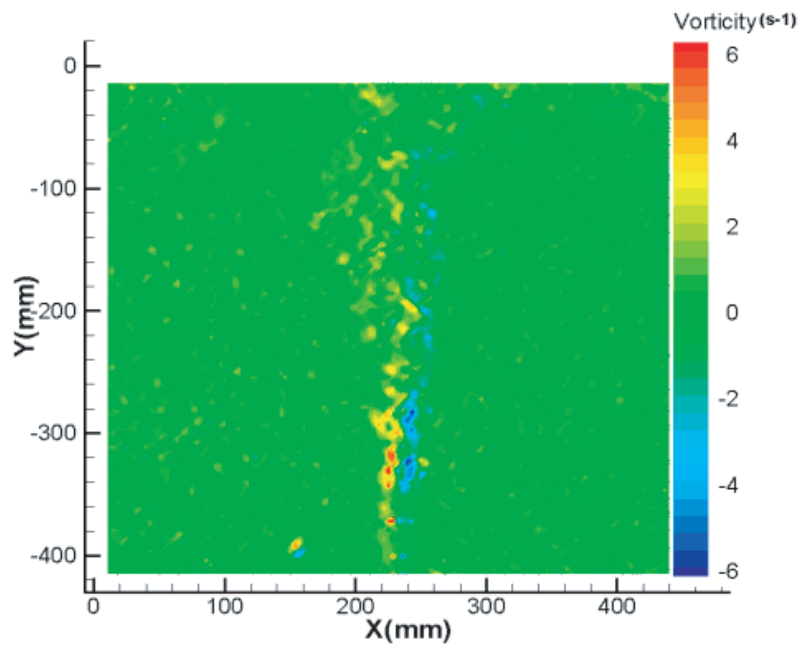

Fig. 3. The vorticity field of upwelling (The initial water temperature was $15^{\circ} \mathrm{C}$ and the heating power was $100 \mathrm{~W}$ )

are a lot of water masses with high ascending speed in DHLU system. These fast-floating water masses lead to the rising of surrounding water, and thus upwelling forms. The production of these fast-ascending water masses is assumed to be the mechanism of upwelling generation in DHLU system (Lv et al. 2014, Li et al. 2018).

As the upwelling in DHLU system is generated by way of fast ascending water masses, the instantaneous velocity field of upwelling in DHLU is unstable. In order to study the basic flow field characteristics of DHLU, we calculated the time averaged mean flow field of 30 continuous instantaneous velocity fields which were measured by 2D PIV. The interval time between two continuous PIV field data was $0.015 \mathrm{~s}$. The mean velocity field seemed to be steady. So, it could be used to analyze the basic characteristics of the flow field in DHLU system.

The mean velocity field of upwelling in typical case is shown in Fig. 4. As the figure shows, the fastest ascending speed in upwelling center occurs at a height of about $100 \mathrm{~mm}$ from the heating source. The upwelling stream entrains more and more new fluid from surroundings when it ascends. And that causes the cross-sectional area of the upwelling keeping expanding when the height grows. And finally, a stream tube of upwelling which shape is just like an upside-down cone is formed. At water surface, water always flows from center to periphery. There is obvious large reflux existing at the outside area of upwelling near the water surface. We will discuss detailed about the specific characteristics of upwelling in DHLU in section 4. 


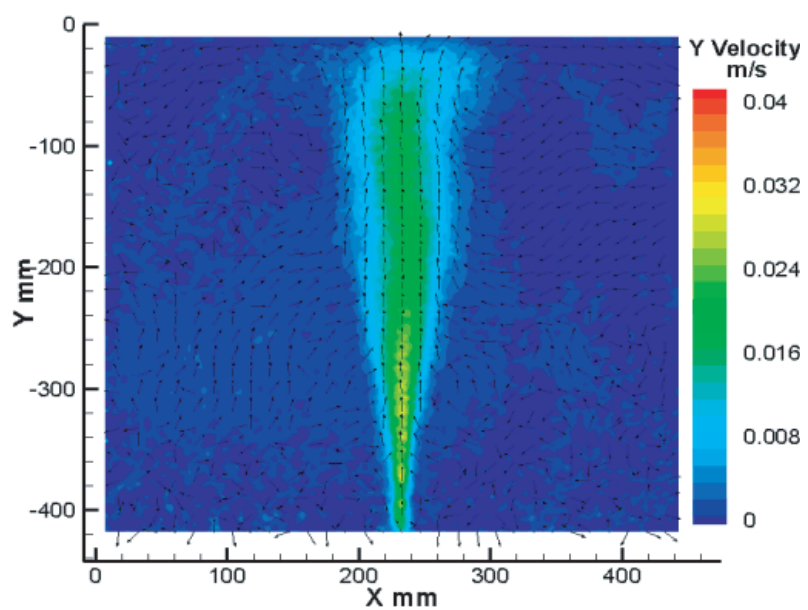

Fig. 4. The mean velocity field of upwelling in typical case (The initial water temperature was $15^{\circ} \mathrm{C}$ and the heating power was $100 \mathrm{~W}$ )

\section{NUMERICAL SIMULATIONS}

\section{Geometric model and computational grids}

Geometric model is built based on the experimental system of DHLU, which was described detailed before. The geometric model has two parts. One is the water tank model with a size of $700 \times 400 \times 500$ $\mathrm{mm}$. The water tank is assumed full of water. The other part is the cylindrical heating stick model with a height of $75 \mathrm{~mm}$ and a diameter of $14 \mathrm{~mm}$. As in reality, in geometric model the heating stick was also fixed vertically at the bottom center of the glass tank, as Fig. 5 shows.

Structured grids were generated by CFD preprocessing software GRIDGEN. To study the heat transfer process nearby the heat source, grids near the

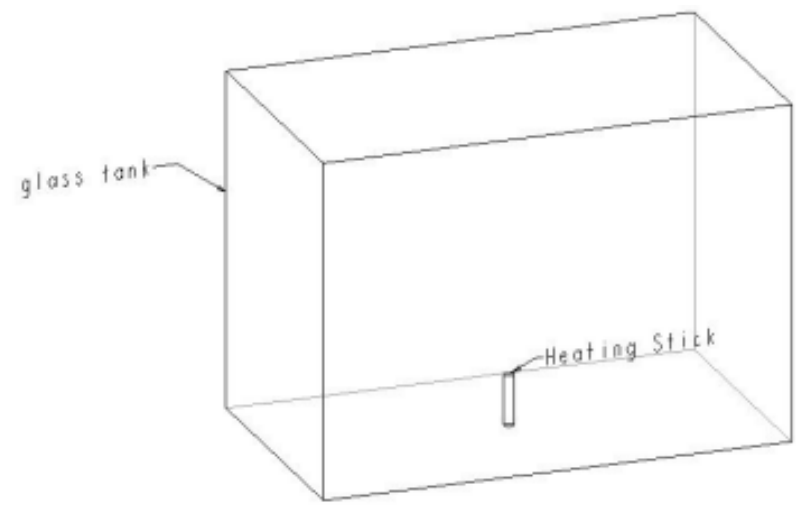

Fig. 5. Geometric model

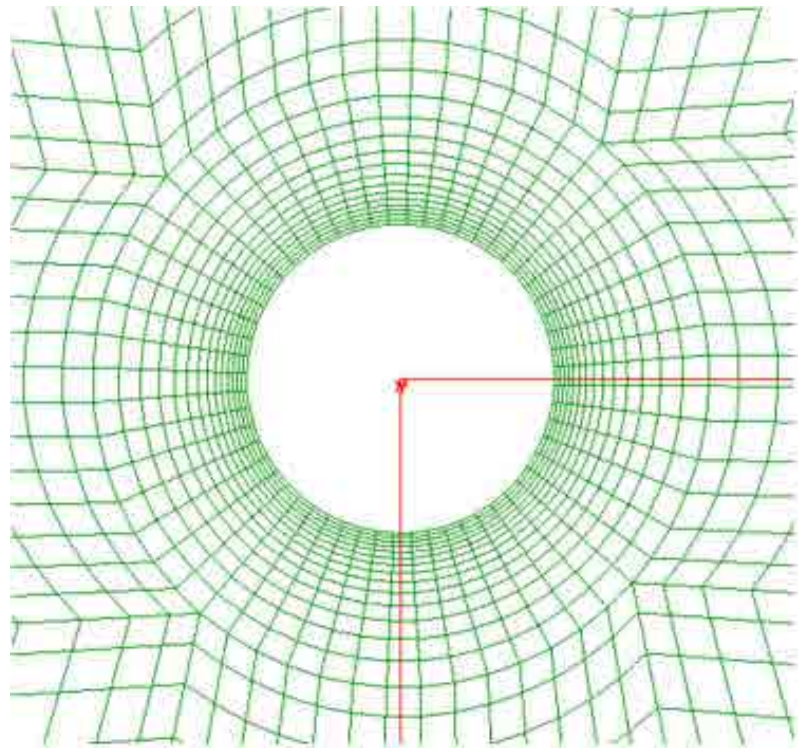

Fig. 6. Densified grids near the heat source

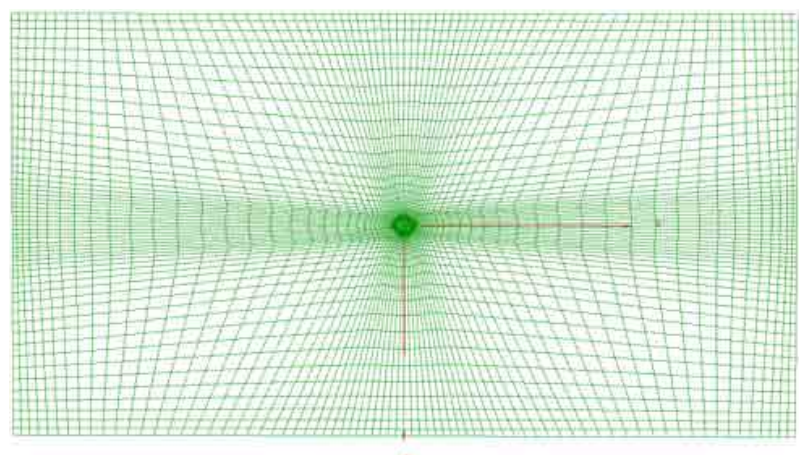

Fig. 7. Densified grids at the center and near the walls

heat source are densified, as Fig. 6 shows. According to the experimental results, the upwelling flow existed major in the area near and above heat source. Especially in the area above the heat source, a great gradient of velocity was observed along the axis of cylindrical heating stick. So, to study the flow characters of upwelling in DHLU, the grids of the area above the heat source and near the axis are densified too. In addition, considering the wall effect of water tank, the grids near tank wall are densified, as Fig. 7 shows. The whole 3D grid system of calculation domain is shown in Fig. 8.

\section{Numerical models and boundary conditions}

As shown in Fig. 2 and Fig. 3, a lot of eddies and high-ascending water masses were observed in DHLU system in experiments. So, the flow of DHLU 


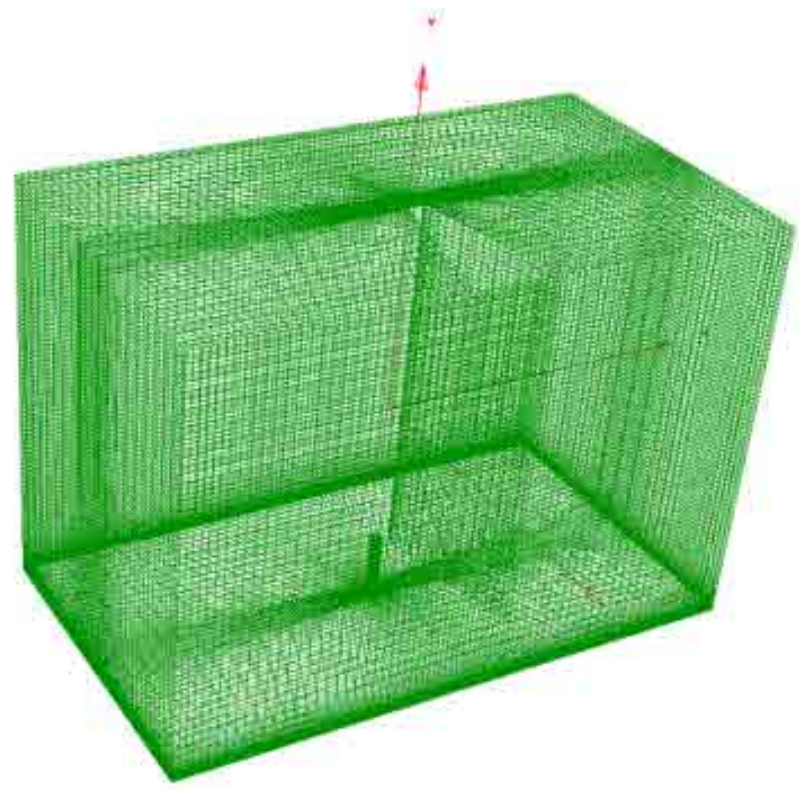

Fig. 8. The whole 3D grid system of calculation domain

is a typical turbulent flow. Therefore, the standard $\mathrm{k}-\varepsilon$ turbulence model was chosen for all numerical simulations in this paper. It is one of the most commonly used models in CFD applications for turbulent cases. The FLUENT module of the famous CFD software ANSYS 14.0 was applied in simulations.

In the numerical simulation, material of fluid was chosen as liquid water. The module "piecewise-liner" was used to define the parameters of liquid water at different temperatures, such as density, specific heat, thermal conductivity and viscosity, as shown in Table I.

For boundary conditions, the five walls of water tank were set as Stationary Wall. As in modeling

TABLE I. PARAMETERS OF LIQUID WATER AT DIFFERENT TEMPERATURES (Liu 2013)

\begin{tabular}{ccccl}
\hline $\begin{array}{c}\mathrm{T} \\
(\mathrm{K})\end{array}$ & $\begin{array}{c}\rho \\
(\mathrm{kg} / \mathrm{m} 3)\end{array}$ & $\begin{array}{c}\mathrm{cp} \\
(\mathrm{J} / \mathrm{kg} \cdot \mathrm{K})\end{array}$ & $\begin{array}{c}\lambda \\
(\mathrm{W} / \mathrm{m} \cdot \mathrm{k})\end{array}$ & $\begin{array}{c}\mu \\
(\mathrm{kg} / \mathrm{m} \cdot \mathrm{s})\end{array}$ \\
\hline 283.15 & 999.7 & 4191 & 0.57 & 0.0013077 \\
293.15 & 998.2 & 4183 & 0.6 & 0.001005 \\
303.15 & 995.6 & 4178 & 0.62 & 0.0008007 \\
313.15 & 992.2 & 4178 & 0.63 & 0.000656 \\
323.15 & 988 & 4178 & 0.64 & 0.0005494 \\
333.15 & 983.2 & 4183 & 0.66 & 0.0004688 \\
343.15 & 977.8 & 4178 & 0.67 & 0.0004061 \\
353.15 & 971.8 & 4195 & 0.67 & 0.0003565 \\
363.15 & 965.3 & 4204 & 0.68 & 0.00032 \\
373.15 & 958.4 & 4212 & 0.68 & 0.00028 \\
\hline
\end{tabular}

ocean environment, the ambient temperature could be seemed as constant value in certain period of time. So, the walls' thermal conditions were all set as with constant temperatures which equal environmental temperature. The side surface of the heating stick was set as Stationary Wall. And as the side surface was the main heating surface of the heating stick, its thermal condition was set as with constant heat flux which was decided by the heating power. The top surface of the heating stick was set as Stationary Wall too. But as there was thermal insulation coating on the top surface of heating stick in experiments, the thermal condition of the top surface in model was also set as adiabatic. The water surface in model was set as Stationary Wall. And its thermal condition was set as with constant temperatures which equals environmental temperature.

\section{Comparison of the experimental and numerical results}

In order to analyze the reliability of the numerical model, we simulated the typical case with a fixed initial water temperature of $15^{\circ} \mathrm{C}$ and a heating power of $100 \mathrm{~W}$, which was conducted in experiments, as Section 2.2 shows. The simulation results were analyzed by the post-processing software's TECPLOT and FIELDVIEW, as shown in Fig. 9.

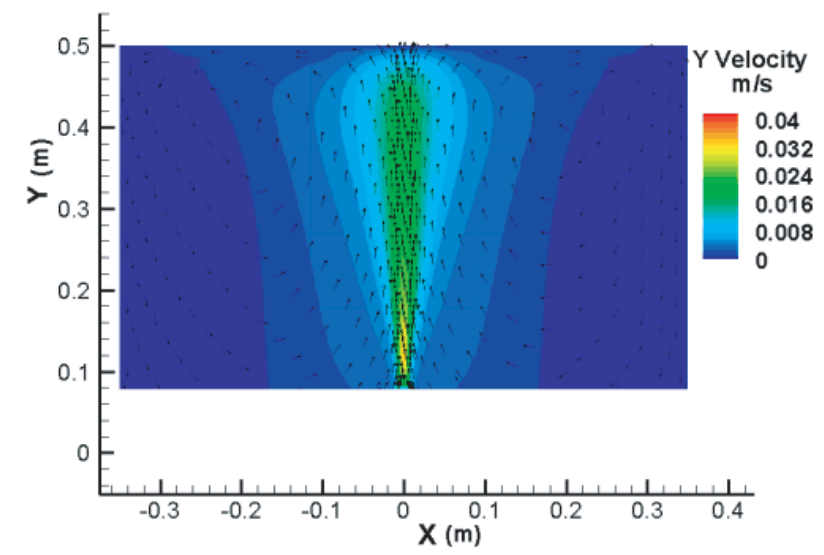

Fig. 9. The velocity field of upwelling in typical case. (The initial water temperature was $15^{\circ} \mathrm{C}$ and the heating power was $100 \mathrm{~W})$

We compared the numerical simulation results and the experimental time-mean results. Results were shown in Fig. 10 to Fig. 12. The velocity distribution characters of the upwelling flow field in simulation results are quite consistent with that in experimental results in the same case, as Fig. 10 shows. To analyze 


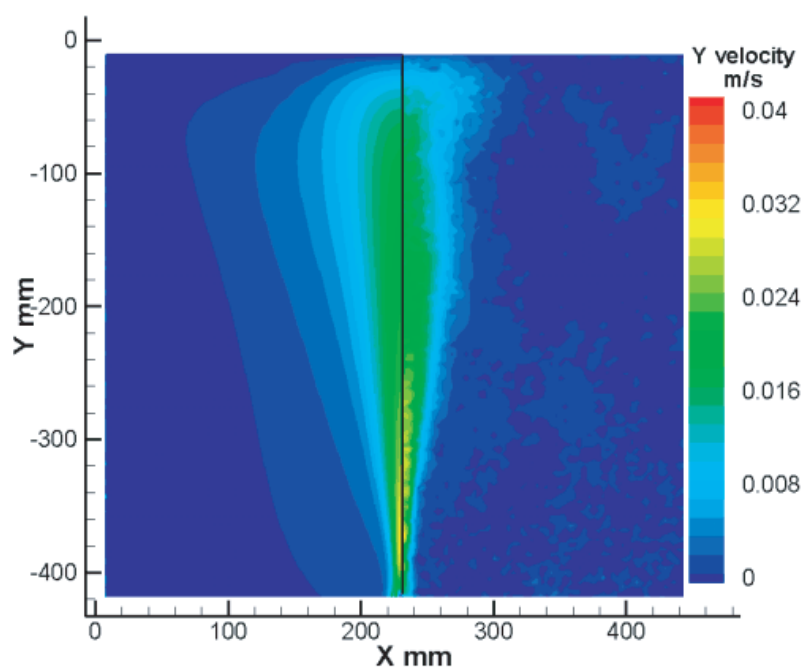

Fig. 10.Comparison of the velocity fields in typical case. (Left is the simulation result, Right is the experimental result)

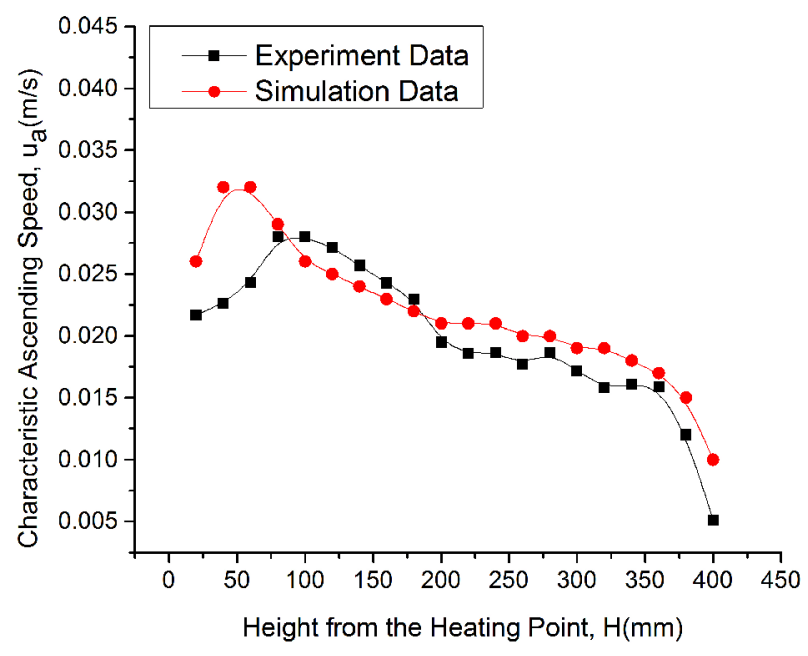

Fig. 11. Comparison of characteristic ascending speeds

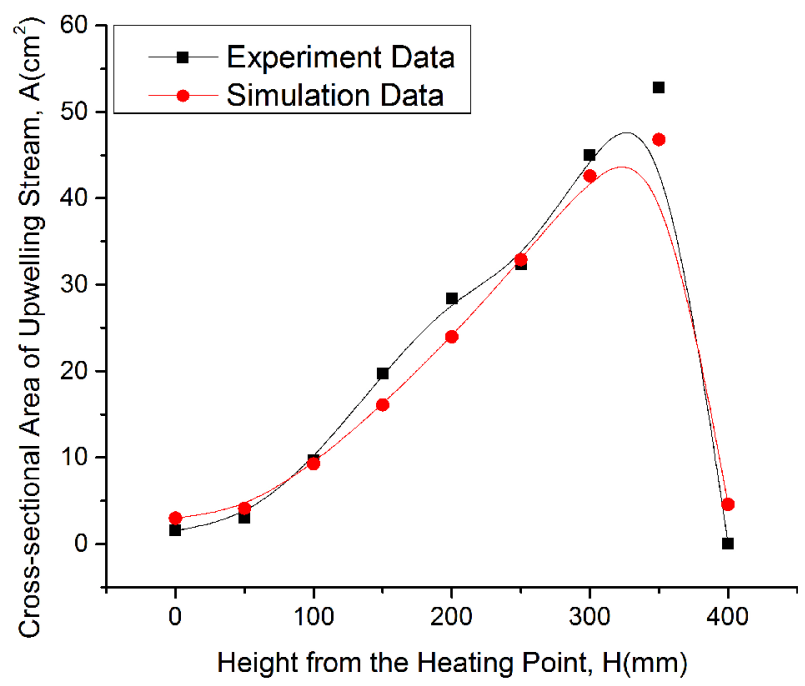

Fig. 12.Comparison of cross-sectional areas the vertical ascending speed changes in upwelling, we choose the ascending speed in upwelling along with the axis of heating stick as the Characteristic Ascending Speed. We compared the characteristic ascending speed and the cross-sectional area of upwelling stream at different height in simulation results and experimental results, as Fig. 11 and Fig. 12 shows. The change of characteristic ascending speed vs. height in simulation results was quite consistent with the experimental results: the characteristic ascending speed increased firstly and then decreased as height increased; And finally, the ascending speed dropped quickly to zero while near the water surface. From sight of the value, the characteristic ascending speed and the cross-sectional area of upwelling stream at different height were also very close to each other for simulation results and experimental results. But the maximum characteristic ascending speed in simulation results was a little higher than that in experimental results. And the height with the maximum ascending speed in simulation results was a little lower than that in experimental results.

In summary, the simulation results could reflect quite well the quantitative and qualitative nature of the flow. The numerical model we built in simulation study was reliable for target cases. So, we studied some basic characteristics of DHLU with numerical simulation method as follows.

\section{RESULT OF THE NUMERICAL CALCULATIONS}

There basic characteristics of the DHLU such as characteristic ascending speed, the cross-sectional area of upwelling stream and the flow rate of upwelled water were studied by numerical simulation under a heating power of $100 \mathrm{~W}$. Three typical initial water temperatures were tested here, including $15^{\circ} \mathrm{C}$, $20{ }^{\circ} \mathrm{C}$ and $25^{\circ} \mathrm{C}$.

\section{The variation rules of characteristic ascending speed in upwelling}

As mentioned before, the characteristic ascending speed was defined as the Y-direction velocity component in upwelling along with the axis of heating stick at different height. That concept can represent the highest ascending speed of time mean flow field at each horizontal section. Fig. 13 shows the characteristic ascending speeds at different heights for three typical initial water temperatures. Results show that in a certain case with a fixed power and a given initial temperature, the characteristic ascending 
speed increased firstly and then decreased slowly as height increased. And when nearing the water surface, the ascending speed dropped quickly to zero. The maximum characteristic ascending speeds in studied cases appeared at a place of about $50 \mathrm{~mm}-100 \mathrm{~mm}$ high from the heating source. With the same heating power, the characteristic ascending speed at a certain height seemed significantly higher in case of $20^{\circ} \mathrm{C}$ initial water temperature than in case of $15^{\circ} \mathrm{C}$. But that characteristic parameter was only a little higher in case of $25{ }^{\circ} \mathrm{C}$ initial water temperature than in case of $20^{\circ} \mathrm{C}$. That means in a certain scale of initial water temperature, when the heating power is kept the same, the characteristic ascending speed at a certain height increases as the initial water temperature increases. But the increasing range decreases gradually.

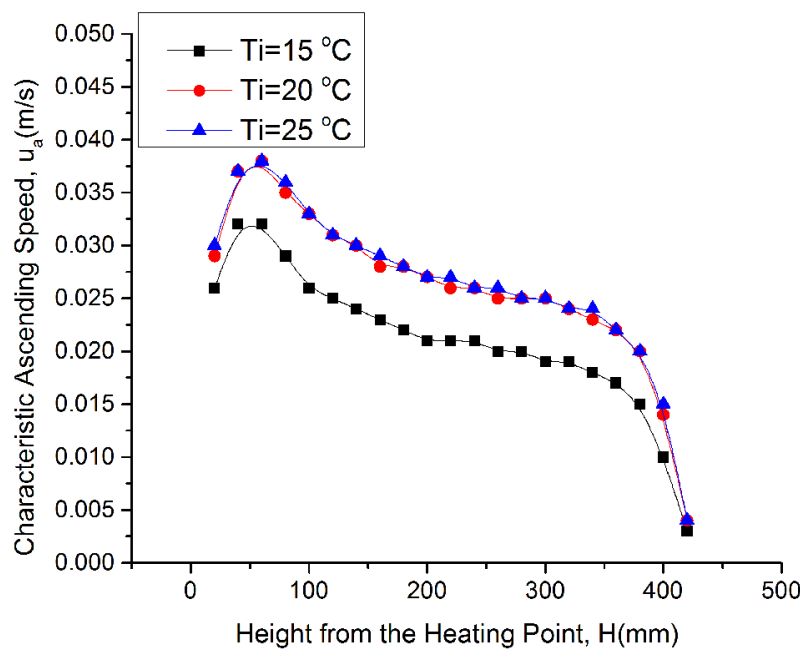

Fig. 13. Characteristic ascending speeds vs. height for different initial water temperatures

\section{The variation rules of upwelling-stream's cross- sectional area}

The upwelling stream's cross-sectional area is defined as the total area of horizontal section which has the positive Y-direction velocity, which means the ascending speed. In this essay, in order to count conveniently, we define upwelling's effective crosssectional area that is the area whose Y-direction velocity is more than $0.01 \mathrm{~m} / \mathrm{s}$.

The simulation results of cross-sectional area at different height for three typical initial water temperatures are shown in Fig. 14. Results show that in certain cases with a fixed power and a given initial temperature, the cross-sectional area of upwelling stream increased firstly and then decreased slowly as height increased. And when nearing the water surface, the ascending speed dropped quickly to zero. In the three studied cases, when the height from heating stick is lower than $350 \mathrm{~mm}$, the increasing speed of cross-sectional area goes faster when the height increases. Because the ascending speeds in areas near the water surface are too small to be counted. So, the counted cross-sectional area decreases while near the water surface. And therefore, the counted results are not quite precise while near the water surface (In cases of this paper, the area higher than $350 \mathrm{~mm}$ from the heating stick can be seem as the area near water surface.) The cross-sectional area of upwelling stream at the water surface is zero while the ascending speed there is zero.

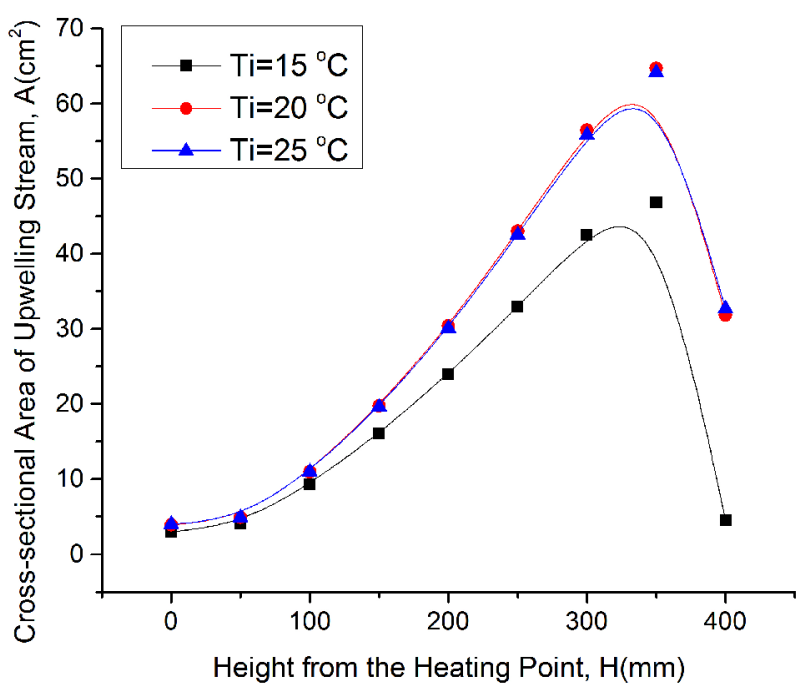

Fig. 14. The cross-sectional area of upwelling stream vs. height with different initial water temperatures

Under a fixed power and a given height, the cross-sectional areas of upwelling stream for the initial water temperature of $20^{\circ} \mathrm{C}$ is obviously larger than $15^{\circ} \mathrm{C}$, especially at a higher height. But these parameters are almost the same between the cases with an initial water temperature of $20^{\circ} \mathrm{C}$ and $25^{\circ} \mathrm{C}$. The initial water temperature plays little influence on the cross-sectional areas while the height is below $150 \mathrm{~mm}$. While the height is higher than 150 $\mathrm{mm}$, the cross-sectional area of upwelling stream increases as the initial water temperature increases in a height scale. But the increasing rate will drop to zero gradually. 


\section{The variation rules of upwelling's flow rate}

The flow rate of whole upwelling is counted through the flow rates in the effective flow area of upwelling, just as follows:

$Q=\sum_{A_{E}} v_{i} \mathrm{~d} A_{i}$

The simulation results of upwelling's flow rate at a heating power of $100 \mathrm{~W}$ for three typical initial water temperatures are shown in Fig. 15. The results show the same variation trend in flow rate with the cross-sectional area.

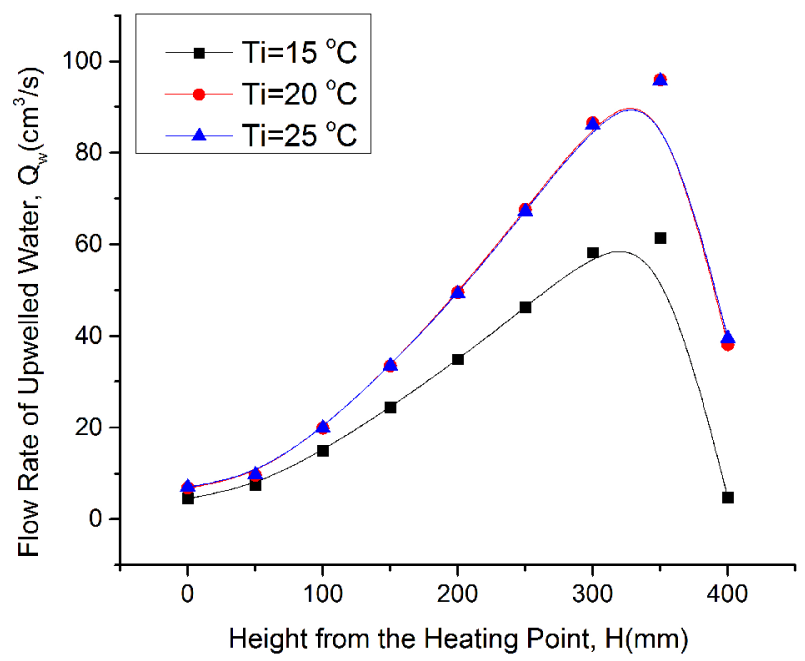

Fig. 15. The flow rate of upwelling vs. height for different initial water temperatures

In certain cases, with a fixed power and a given initial temperature, the flow rate of upwelling increased as the height increased firstly and then decreased while near the water surface. In the three studied cases, when the height from heating stick is lower than $350 \mathrm{~mm}$, the increasing rate of upwelling's flow rate goes faster when the height increases. But the counted flow rate near the water surface is not quite precise because of the deviation about the counted cross-sectional area near water surface.

Under a fixed power and a given height, the flow rate of upwelling stream for the initial water temperature of $20^{\circ} \mathrm{C}$ is obviously larger than $15^{\circ} \mathrm{C}$, especially at a higher height. But that parameters are almost the same between the cases with an initial water temperature of $20^{\circ} \mathrm{C}$ and $25^{\circ} \mathrm{C}$. The initial water temperature plays little influence on the upwelling's flow rate while the height is below $150 \mathrm{~mm}$. While the height is higher than $150 \mathrm{~mm}$, the flow rate of upwelling increases as the initial water temperature increases. But the increasing rate will drop to zero gradually. Overall, the drop of initial water temperature (ambient temperature) is not favorable for the production of upwelling. In studied cases in this paper, a maximum flow rate of $95.9 \mathrm{~cm}^{3} / \mathrm{s}$ was got.

\section{CONCLUSIONS}

In this paper, the characteristics of the flow field in DHLU in open surroundings were studied by PIV system. And the simulation model was built based on the experimental results. And then the numerical simulation studies were carried out to study the influences rules of several important parameters at typical heating power. The PIV studies indicated that the upwelling in DHLU system is mainly driven by the masses with high ascending speed. It is reasonable to use the $k-\varepsilon$ turbulence model to study the flow field of DHLU in simulation. The simulation results can reflect the basic features and the variation rules of simulated object. The simulation studies showed that the characteristic ascending speed increases firstly and then decreases while the height from the heating source increases. The maximum value appeared at a height scale of $50 \mathrm{~mm}-100 \mathrm{~mm}$ from the heating source in this paper. The variation trends of the upwelling's flow rate are consistent with the cross-sectional area of upwelling stream: both the parameters are increases firstly and then decreases as the height increases. The maximum value of above two parameters appeared at a height of $350 \mathrm{~mm}$ in this paper. The drop of ambient temperature is not favorable for the production of upwelling. A flow rate as high as $95.9 \mathrm{~cm}^{3} / \mathrm{s}$ was reached in studied cases in this paper.

\section{ACKNOWLEDGEMENTS}

Authors wish to acknowledge the sponsor of the Zhejiang Provincial Natural Science Foundation of China (No. LY16E090006), the National Natural Science Foundation of China (No.51209062, No.11472095), the Zhejiang Provincial Science and Technology Project (No. 2018C04002)

\section{REFERENCES}

Anees M.M., Qasim M. and Bashir A. (2017). Physiological and Physical Impact of Noise Pollution on Environment. Earth Science Pakistan. 1(1), 08-11. 
Angelicque W., Karin B., Eric G., Ricardo L., Steve P., Blake W. and David K. (2010). An open ocean trial of controlled upwelling using wave pump technology. J. Atmos. Ocean. Tech. 27, 385-396.

Brian, K. (2003). Enhancing fish stocks with wavepowered artificial upwelling. Ocean. Coast. Manage. 46, 901-915.

Cheung Y., Lam O., Lun S., Pang C., Wu K.W. and Leung W.K. (2017). Electrical Stimulation for Eggs and Semen on Tavhypleus Tridentatus Collected from Local Restaurants in Hong Kong. Malaysian Journal of Sustainable Agriculture. 1(2), 01.

Dzida M. and Girtler J. (2016). Operation Evaluation Method for Marine Turbine Combustion Engines in Terms of Energetics. Polish Maritime Research. 23 (4), 67-72.

Fan W., Chen J., Pan Y., Huang H., Chen C.T.A. and Chen Y. (2013). Experimental study on the performance of an air-lift pump for artificial upwelling. Ocean Eng. 59, 47-57.

Franco H., Gavín-Quinchuela T., Alvarado-Macancela N. and Carrión-Mero P. (2017). Participative analysis of socio-ecological dynamics and interactions. A case study of the manglaralto coastal aquifer, santa elenaecuador. Malaysian Journal of Sustainable Agriculture. $1(1), 19-22$.

Fu H. and Liu X. (2017). A Study on the Impact of Environmental Education on Individuals' Behaviors Concerning Recycled Water Reuse. Eurasia Journal of Mathematics Science and Technology Education. 13 (10), 6715-6724. doi: 10.12973/ejmste/78192.

Fu H.L. and Liu X.J. (2017). Research on the Phenomenon of Chinese Residents' Spiritual Contagion for the Reuse of Recycled Water Based on SC-IAT. Water, 9 (11), 846.

Halin N.I.A., Huyop F., Hamid H.A., Halim K.B.A. and Hamid A.A.A. (2017). In silico binding interactions of dehalogenase (Dehe) with various haloalkanoic acids. Science Heritage Journal. 1(1), 04-06.

Isaacs J.D., Castel D. and Wick, G.L. (1976). Utilization of the energy in ocean waves. Ocean Eng. 3, 175-187.

Jeffrey J.P., Evan, H. and Donald RK. (2001). The transition zone chlorophyll front, a dynamic global feature defining migration and forage habitat for marine resources. Prog. Oceanogr. 49, 469-483.

Kazuyuki O. and Alan J.M. (2003). Real sea experiment of ocean nutrient enhancer "TAKUMI" upwelling deep ocean water. Ocean. P. 881-885.

Kazuyuki O. and Hiroyuki N. (1999). The deep ocean water upwelling machine using density current-Creation of fishing ground and absorption of CO2. Oceans'99 MTS/IEEE, 2, 1019-1024.

Khan A.M., Yusoff I., Abu Bakar N.K., Abu Bakar A.F., Alias Y. and Mispan M.S. (2017). Accumulation,
Uptake and Bioavailability Of Rare Earth Elements (Rees) In Soil Grown Plants From Ex-Mining Area In Perak, Malaysia. Applied Ecology and Environmental Research. 15 (3), 117-133.

Kori A.H., Jakhrani M.A., Mahesar S.A., Shar J.Q., Jagirani M.S., Shar A.R., and Sahito O.M. (2018). Risk assessment of arsenic in ground water of Larkana city. Geology, Ecology, and Landscapes. 2(1), 8-14.

Leng J.Y., Huang H.C., Chen J.W., Fan W., Han G.E., Shan L., Liu M.Z., Yang J. and Chen Y. (2014). Influence of air-lift artificial upwelling on water temperature. J. Mech. Electr. Eng. 4, 442-445.

Li Y., Yang P. and Wang H. (2018). Collecting Coal-Fired Power Environmental Tax to Promote Wind Power Development and Environmental Improvement. Acta Scientifica Malaysia. 2(1), 5-8.

Li Z., Qi S. and Wei D. (2018). Empirical Research on the Relationship between Natural Gas Consumption and Economic Growth in the Northeast Asia. Energy and Environment.

Liang N.K. and Peng H.K. (2005). A study of air-lift artificial upwelling. Ocean Eng. 32, 731-745.

Liu C. (1999). Research on artificial upwelling and mixing at the University of Hawaii at Manoa. IOA Newsl, $10,1-8$.

Liu C.C.K. and Jin Q. (1995). Artificial upwelling in regular and random waves. Ocean Eng. 22, 337-350.

Liu G.Q., Ma L.X. and Xiang S.G. (2013). Chemistry and Chemical Properties Datasheet Inorganic volume. Chemical Industry Press, Beijing.

Lv M., Yan X., Nie X., Pan H.C. and Liu H.Q. (2014). Experimental studies of differential heating for artificial upwelling. Comput. Model. New Technol. 26, 299-303.

McClimans T.A., Handa A., Fredheim A., Lien E. and Reitan K.I. (2010). Controlled artificial upwelling in a fjord to stimulate non-toxic algae. Aquacult. Eng. $42,140-147$.

Mi C., Zhang Z.W. and Huang Y.F. (2016). A Fast-Automated Vision System for Container Corner Casting Recognition. Journal of Marine Science and Technology. 24(1), 54-60.

Pan H. and Eranti E. (2007). Applicability of air bubbler lines for ice control in harbors'. China Ocean Eng. 21, 215-224.

Pan H. and Eranti E. (2009). Flow and heat transfer simulations for the design of the Helsinki Vuosaari harbor ice. Cold Reg. Sci. Technol. 55, 304-310.

Pan Y.W., Fan W., Huang T.H., Wang S.L. and Chen C.T.A. (2015). Evaluation of the sinks and sources of atmospheric $\mathrm{CO} 2$ by artificial upwelling. Sci. Total Environ. 511, 692-702.

Rogers J.N., Parrish C.E., Ward L.G. and Burdick D.M. (2016). Assessment of Elevation Uncertainty in Salt 
Marsh Environments using Discrete-Return and FullWaveform Lidar. Journal of Coastal Research. (76), 107-122.

Ryther J.H. (1969). Photosysthesis and fish production in the sea. Science. 166, 72-76.

Singh A., Kewat M.L. and Sondhia S. (2018). Studies on the effect of day time application of herbicide mesosulfuronmethyl on soil microbial communities of wheat rhizosphere. Journal of Environmental Biology. 39 (1), 59-65. doi: 10.22438/jeb/39/1/MRN-562.

Tan P.F., Hanafiah M.M., Mokhtar M.B. and Harun S.N. (2017). Rainwater Harvesting System: Low Awareness Level Among University Students in a High Rainfall Tropical Country. Malaysian Journal of Sustainable Agriculture. 1(2), 09-11.

Teng Y. and Zhou Q. (2017). Environmental effect of Sudan I-IV: adsorption behaviours and potential risk on soil. Acta Scientifica Malaysia. 1(1), 16-17.

Tian X.Q., Pan H.C., Zhang H. and Zheng Y. (2014). Experimental study of the influence of the bubble size on the upwelling flow rate. Chinese J. Hydrodyn. 5, 586-591.

Tsubaki K., Maruyama S., Komiya A. and Mitsugashira H. (2007). Continuous measurement of a water induced by the perpetual salt fountain artificial upwelling of deep sea. Deep-Sea Res. I. 54, 75-84.
Usman M., Yasin H., Nasir A. and Mehmood W. (2017). A Case Study of Groundwater Contamination Due to Open Dumping of Municipal Solid Waste in Faisalabad, Pakistan. Earth Sciences Pakistan. 1(2), 12-13.

Williamson N., Komiya A., Maruyama S., Behnia M. and Armfield S.W. (2009). Nutrient transport from an artificial upwelling of deep sea water. J. Oceanogr. 65, 349-359.

Yang A., Han Y., Li S., Xing H., Pan Y. and Liu W. (2017). Synthesis and comparison of photocatalytic properties for Bi2WO6 nanofibers and hierarchical microspheres. Journal of Alloys and Compounds. 695, 915-921. doi: 10.1016/j.jallcom.2016.10.188.

Yu Z.G., Mi T.Z., Yao Q.Z., Xie B.D. and Zhang J. (2001). Nutrients concentration and changes in decade-scale in the central Bohai Sea. Acta Oceanol. Sin. 20, 65-71.

Zaidi N.A., Hamid A.A.A. and Hamid H.A. (2017). Lactic acid bacteria with antimicrobial properties isolated from the instestines of japanese quail (Coturnix Coturnix Japonica). Science Heritage Journal. 1(1), 10-12. 